\title{
THE CRIMINAL WRONGDOING IN THE CRIME OF TAX EVASION
}

\section{A INFRAÇÃO CRIMINAL NO CRIME DE EVASÃO TRIBUTÁRIA}

\section{ALEX VOLNEI TEIXEIRA}

Professor at the First Nations University of Canada, Ph.D. Researcher CNPq Research Group Cooperation and Relations Contractual Development and sustainability of the Americas. Work and research in the areas of development and Virtual Environments Innovation Enterprise, with emphasis on Strategic Management, Information Technology, Information Systems, Urban Management, Smart Cities, Digital Cities and Digital Strategic City.

FABIO ROBERTO D'AVILA

Professor at Law School and Criminal Sciences Graduation Program - Pontífica Universidade Católica do Rio Grande do Sul (PUCRS). Criminal lawyer. E-mail: davila@davilaoliveira.adv.br

MARION BACH

Professor of Criminal Law at UNICURITIBA and FAE (Curitiba / PR). Criminal lawyer. E-mail: marion@marionbach.com.br

\section{ABSTRACT}

Objectives: The article's objectives were to describe the distinction in the core of action devaluation and result devaluation, between the illegality of tax evasion within the scope of Administrative Law and tax crime.

Methodology: The methodology was based on the deductive method, which characterized the present research as descriptive of qualitative nature, through a comparative bibliographic review, the circumstantial analysis of two specific cases and object of a complaint involving tax evasion and judged by the Brazilian Judiciary. The comparative Brazilian and international bibliographic review converge on the dogmatic concept of a criminal offence and an administrative law. 
Result: The result presented a critical analysis of the explored cases, which resulted in evidence that the Public Ministry and the Brazilian Courts, due to dogmatic mistakes, do not make, with regard to tax evasion, the correct distinction between administrative and criminal offences.

Contributions: The article emphasizes the result of the research that established a dogmatic analysis, with emphasis on the distinction between the criminal offence and the merely administrative offence. As a contribution, the article offered a deep discussion and theoretical knowledge of an academic nature regarding the theme.

Keywords: tax evasion; tax crimes; fraud; typical illicit.

\section{RESUMO}

Objetivo: O objetivo deste artigo foi traçar a distinção nos núcleos de desvalor de ação e desvalor de resultado, entre o ilícito de sonegação no âmbito do Direito Administrativo e o crime tributário.

Metodologia: A metodologia fundamentou-se no método dedutivo, que caracterizou a presente pesquisa como descritiva de natureza qualitativa, por meio de uma revisão bibliográfica comparada e na análise circunstancial da realidade em dois casos concretos, objeto de denúncia envolvendo sonegação fiscal e julgados pelo Poder Judiciário brasileiro. A revisão bibliográfica brasileira e internacional comparada convergem no conceito dogmático de um ilícito penal e um licito administrativo.

Resultado: O resultado apresentou uma crítica aos casos concretos explorados, que resultou em evidencia que o Ministério Público e os Tribunais brasileiros, por equívocos dogmáticos, não realizam, no que refere à sonegação fiscal, a correta distinção entre ilícito administrativo e ilícito penal. Acabam, portanto, equiparandoos.

Contribuições: $O$ artigo enfatiza o resultado da pesquisa que estabeleceu uma análise dogmática, com ênfase na distinção entre o ilícito penal e o ilícito meramente administrativo. Ainda como contribuição, o artigo aprofundou a discussão e 0 conhecimento teórico de caráter acadêmico referente a temática.

Palavras-chave: Crime tributário; Sonegação fiscal; llícito-típico; Fraude; Desvalor de ação; Desvalor de resultado. 


\section{INTRODUCTORY ELEMENTS ${ }^{1}$}

Tatbestandsmäßigkeit is an essential concept of tax law and is related to the phenomenology of incidence. Becker notes that the term hypothesis of incidence has been chosen to refer to what other authors point to as phatic support, "fattispecie," "hecho imponible," tax assumption, and herewith particular interest "Tatbestand." (BECKER, 2007, p.336).

It is through the incidence hypothesis that "the legislator cuts real-life events and impute them the strength of, reported incompetent language, elicit the behaviours that one understands valuable" (CARVALHO, 2013, p.254). Read: The legislator chooses real-life events that one considers "tax-relevant" and describes them in detail in the legal text.

[...] We say that there was the subsumption when the fact (legal tax fact constituted by the language prescribed by positive law) maintains the absolute identity with the normative design of the hypothesis (tax hypothesis). When this fact becomes concrete, it is automatically and infallibly, as Alfredo Augusto Becker says, the abstract bond by which the active subject becomes the holder of the subjective public right to demand the benefit. In contrast, the taxable person will be in the contingency to fulfill it (CARVALHO, 2013, p.254).

Therefore, the idea of Tatbestandsmäßigkeit in tax law concretizes the principle of strict legality, provided for in art. 150, inc. I, of the Brazilian Federal Constitution. This device indicates that, without prejudice to other guarantees legal guaranteed to the taxpayer, it is prohibited to the Union, to the States, to the Federal District and to the Municipalities to demand or increase tribute without the law establishing it.

Therefore, there is a tax obligation, it is indispensable that there be exact subsumption of the fact concretely occurred to the legal description, that is, to the hypothesis of tax incidence. The norm has the perfect fit for the point, and the tax legal fact (VIERA, 1993, p.62) is born. As part of the doctrine stands, it is necessary

${ }^{1}$ T.N.: (a) All quotes are free translation from portuguese to english. (b) We have chosen to keep some expressions in German, since there is little compatibility of some nomenclatures with the English language. 
to observe the criteria ${ }^{2}$ of the core rule of incidence that must be analyzed and fulfilled. The tax incidence hypothesis - as it is called the description - is composed of the material criterion (CARVALHO, 2013, p.261), that is, by the personal behaviour (conduct), by the temporal criterion ${ }^{3}$, which, as the name evidence, deals with the conditions of time and, finally, by the spatial criterion (VIEIRA, 1993, p.63), which clearly treats the condition of place.

This set of criteria, however, confers a formalistic character to the Tatbestandsmäßigkeit in the tributary field. These are elements of an essentially objective nature - verb and complement, place and time -, with no more space for references of a substantial character or subjective elements related to intention and/or guilt. ${ }^{4}$ The tax unlawful is born, fundamentally, aiming at objective accountability. In this sense, it does not surprise the perception of the tax infraction as "any action or omission that, directly or indirectly, represents the noncompliance with the legal duties established in tax laws" (CARVALHO, 2013, p.470). Noncompliance, it is worth recording, maybe due to non-payment of payable taxes or, nonetheless, failure to pay attention to ancillary obligations (instrumental or formal obligations) $)^{5}$.

In criminal law, on the other hand, the activities happen very differently.

Although the criminal and tributary terminology sometimes keeps some

2 Such nomenclature presents variations in doctrine field. Fabio Fanucchi, for example, means "elements" of the core rule of incidence. Geraldo Ataliba adopts the notion of "aspects" of the core rule of incidence. The nomenclature we chose to use in the present study ("criteria") is suggested by Paulo de Barros Carvalho and also adopted by José Roberto Vieira.

${ }^{3}$ The spatial criterion allows the recognition of the condition that marks the juridical tax event in space, restricting it to a certain extent of the territory. It should be made clear, however, that such a criterion does not overlap with the geographical breakdown of the territorial scope of validity or effectiveness of the tax Law. (VIEIRA, 1993, p. 63).

4 This does not mean a complete dismissal of subjective elements by tax law. "Although the general principle - in the field of tax infractions - is that of objective liability, the legislator is not prevented from creating figures of subjective misconduct's tiypicity. They are the avoidance, the fraud and the collusion" (CARVALHO, 2013, p. 472). Such elements, however, are not essential to the configuration of the unlawfulness. On the contrary, they are considered exclusively when calculating (or, for a better understanding of penalists, dosimetry) the penalty (fine), and not when analyzing (the existence of) Tatbestandsmäßigkeit.

${ }^{5}$ The National Tax Code defines, in art. 113, par. 2, that an ancillary obligation derives from the tax legislation and has as its object the benefits, positive or negative, with interest in tax collection or inspection. "It is, in fact, as the doctrine has noted, prescriptions of doing and not doing, directly established in law, in the interest of the Treasury, rather, in the interest of collection or inspection." FERRAZ JUNIOR, 2005, p.264. 
proximity, like the Tatbestandsmäßigkeit itself, the concepts do not find equivalence and refract themselves, in dogmatic terms, in a particular way. The Tatbestand in criminal law, for example, even if taken in its strict sense conception, can no longer be understood as a simple legal Tatbestand, in line with its well-known nineteenthcentury conception (gesetzlicher Tatbestand). On the contrary. Today, it consists of a complex normative elaboration, teleologically guided by its material content, to assume, on the one hand, the central role in the recognition and constitution of the criminal wrongdoing and, on the other, simultaneously the position of delimitation element of the very legitimacy of the criminal-law intervention. The Tatbestand stricto sensu is, therefore, the bearer of the legal-penal ratio itself, and it is always Unrechtstatbestand.

Such differences explain, to a large extent, the constant misconceptions surrounding the criminal tax offence. Attempts of simple conceptual transposition are not uncommon in criminal practice, resulting in accusations that are incapable of expressing, even minimally, a legitimate criminal-law claim. The present text is therefore concerned with this specific issue: the misunderstandings about the Unrechtstatbestand of a tax crime, with special attention to Article 1 of Brazilian Law $8.137 / 90$, and its specificities. The general aim is, after all, to propose elements for a better delimitation of the scope of legitimate incidence of criminal law in the tax field.

To do so, before the necessary theoretical development, we will present two real cases, for the purpose of illustration, which will be briefly taken up at the end of this study.

\section{A BRIEF EXPOSITION OF REFERENCE CASES}

The two cases were chosen as reference for the present study deal with ICMS (Tax on Circulation of Goods and Services). It should be noted, however, that the discussions that constitute its background are quite common and recurrent in forensic practice, not limited to this modality of tribute.

(a) First case: The Public Prosecutor's Office understood by indicting, as 
incurred in art. $1^{\circ}$, II, of Law 8137/90, the managing partner of a company that produces and sells food products in the state of Santa Catarina/Brazil.

According to the prosecutor's office, in a given period, the managing partner would have promoted the reduction of taxes due to the State of Santa Catarina, through insertions of undue ICMS credits in a mandatory fiscal book.

In fact, the managing partner acted as follows: in order to carry out the commercial activity, one acquired ox carcasses in the States of Paraná and Mato Grosso, and then divided these carcasses into smaller pieces for commercialization. Due to the principle of non-cumulative ICMS, they were provided for in art. $155, \S 2^{\circ}$, I, of the Brazilian Federal Constitution, the managing partner was credited with the values - and strictly of the amounts - of ICMS subscribed in the invoices issued when the carcass purchases were made.

For the Public Prosecutor's Office, such credits were considered undue because the RICMS of the State of Santa Catarina does not permit the exploitation of credit, even if detached in a tax document, from operations originating from units of the federation that have granted unilateral tax benefits (without approval in the Conselho Fazendário - CONFAZ) - as Paraná and Mato Grosso.

In other words, the prosecutor understood that if the taxpayer's interpretation does not coincide with the interpretation of the tax authorities, being the conduits chosen by the taxpayer guided by the interpretation of the tax authorities, the criminal tax offence will be born. In the same sense, it was the Judiciary's understanding - at least in the beginning. So much so that when the Prosecutor's Office carried out the initial analysis on the viability of the prosecution, it received such a complaint.

(b) Second case: The Public Prosecutor's Office decided to indict the managing partner of a road transport company, located in the State of Paraná, for the practice of art. 1으. I, II and IV of Law 8137/90, due to the deliberate suppression of tax burden related to ICMS.

The Public Prosecutor's Office affirmed that the indicted would have acted through fraud and misused ICMS credits to offset monthly tax debts of the company, causing damage to the State of Paraná. This is because, despite the RICMS of Paraná (in force at the time), authorized - due to the constitutional principle of non- 
cumulative that interstate and inter-municipal transportation companies appropriated the tax credits paid in operations involving the purchase of rolling stock and maintenance of the fleet, as well as goods destined for permanent assets, also required and conditioned such appropriation to the demonstration, by vehicle of the fleet, of the effective use of materials and merchandise.

In this particular case, the managing partner, according to the complaint, would have made use of ICMS credits for the purchase of vehicle fleet maintenance materials, without, however, having produced the reports required by the RICMS, resulting in the occurrence of the criminal tax offence.

\section{THE UNRECHTSTATBESTAND IN CRIMINAL LAW}

\subsection{THE CONCEPT OF TATBESTAND IN THE STRICT SENSE: INTRODUCTORY ELEMENTS}

The gesetzlicher Tatbestand of crime (praeceptum legis) consists of the description of the criminal fact by the criminal law, by means of which the matter of prohibition is delimited. It can be properly understood as a partial implementation of the principle of legality ${ }^{6}$, in accordance with the provisions of art. $1^{\circ}$ of the Brazilian Criminal Code: "There is no crime without previous law that defines it. There is no penalty without prior legal notice."

This precise way of conceiving the criminal Tatbestand, still of great value for the theory of the crime, go back to the writings of Ernst Beling, in particular to his 1906 Die Lehre von Verbrechen. Before him, the notion of criminal Tatbestand was already known, but as a concept is very close to crime as a whole. ${ }^{7}$ Beling, on the

\footnotetext{
${ }^{6}$ Please note that legal Tatbestand and Garantietatbestand are not coincidental categories (see below).

7 In historical terms, according to Stratenwerth and Kuhlen, the concept of criminal Tatbestand refers to that of corpus delicti, already present in Farinacius's work of 1581. At that time, it corresponded to the set of exterior elements of a concrete criminal fact. Only from the 18th century, the concept of criminal Tatbestand would represent the set of constituent elements of a particular crime (STRATENWERTH; KUHLEN, 2004, p. 74). See also KINDHÄUSER, 2008, p. 65.
} 
other hand, proposed a much narrower conception, no longer as a synonym for crime, but as a fundamental "moment of the concept of crime," from which crime theory should be constructed (BELING, 1906, p.1).

Later studies, however, began to unfold the concept of Tatbestand from the attribution of diverse contents and functions, leading to a departure from the unitary concept of Beling ${ }^{8}$ and to varied concepts, such as, by way of example, so-called "action Tatbestand," "total Tatbestand," "Tatbestand of error," "Tatbestand of culpability," among others.

It is quite true that this multiplicity of concepts involving the notion of criminal Tatbestand, although aspiring to greater clarity and accuracy, rarely gives rise to its exact opposite, making terminological consensus difficult and leading to misunderstandings in the use of its various meanings. This, however, does not prevent us from recognizing, on the other hand, that some distinctions are absolutely essential and can not be dispensed with.

In what concerns the present article, the problem arises in relation to the content of the so-called Tatbestand in the strict sense ${ }^{9}$, that means, with regard to the concept of Tatbestand that must be taken as reference to the process of subsumption, revealing the fact as tatbestandmässig (according to the Tatbestand) or

\footnotetext{
8 Illustrative in this context is Engisch's well-known 1954 paper on normative elements of Tatbestand. In it, the author already accurately identified five different Tatbestands of concepts, organized from the widest to the narrowest: (i) Tatbestand in the sense of the crime theory, related to all the material presuppositions necessary for the application of punishment, including objective conditions of punishability and leaving only the conditions of action (Strafverfolgungsbedingungen); (ii) Tatbestand of crime (Verbrechenstatbestand), consisting of all the elements of crime ("general and special, positive or negative, written or not"), leaving out the conditions of procedurality (Strafverfolgungsbedingungen) and "external conditions of punishability, "such as, for example, the absence of pardon, insofar as they do not interfere with the existence of the crime itself; (iii) Tatbestand of guarantee (Garantietatbestand), to understand all elements of crime from the perspective of the principle of legality (nullum crimen sine lege), including elements of illegality and guilt; (iv) Unrechtstatbestand, consisting of all the elements ("general or special, positive or negative, written or not, objective or subjective") that constitute the "objective content of the criminal offense" ("injury to interests, social damage, etc. ") and that, to this extent, it is presented as" ratio essendi da ilicitude "- the Unrechtstatbestand does not include elements of culpability; and finally, the (v) legal Tatbestand (gesetzlicher Tatbestand), corresponding to the "driving concept" (Leitbild) of Beling, in the terms already discussed above. Of all this is the most restricted concept. It does not reach the elements of culpability and, as regards the causes of justification, it depends on whether or not to accept the controversial theory of negative elements of the Tatbestand. ENGISCH, 1954, p. 130 ss.

9 See WESSELS; BEULKE, 2000, p. 37; STRATENWERTH; KUHLEN, 2004, p. 75 ss.; RENGIER, 2013, p. 44. In a similar sense, but referring to Tatbestand in a technical sense. (FUCHS, 2012, p. 90 s.) and in a dogmatic sense (STEININGER, 2013, p. 97).
} 
not tatbestandmässig (not according to the Tatbestand).

The category of Tatbestand in the strict sense must correspond, in dogmatical terms, to the violation of the normative precept that underlies it, be it prescriptive or prohibitive (STRATENWERTH, 2004, p.75) In fact, it is the legal description of this precise violation, and therefore, legislative expression of the "denial of values" (CORREIA, 1999, p.273 ss) that the criminal law seeks to protect. This fact, if well understood, makes the Tatbestand a formulation essentially normative and teleologically oriented, the formulation that holds in the material dimension its most profound ratio.

In strictly logical-analytical terms (FARIA COSTA, 2015, p. 217), Tatbestandsmäßigkeit corresponds to the first judgment of the value of the analytical structure of crime. However, the same does not occur from an ontological perspective. The Tatbestand is not a Prius, but a Posterius: it is nothing more than the result of legislative intervention on a state of things already valued negatively and whose devalue, in addition to preceding it, motivates and confers foundation. The Tatbestand is, therefore, only the "bearer of the juridical-penal valuation that the judgment of unlawfulness expresses."10

Creating a Tatbestand of homicide, the state does not inaugurate the devaluation of the act of killing and this urge as a crucial point. In this scenario, happens the recognition, by criminal law, of the previous depreciation of such behaviour, from criminal referents of a trans-systematic nature, among which, in particular, though not only, the offence to legal-criminal goods. Not of any devaluation but that who proves intolerable, truly unbearable for life in Community. In this case and only for then, given this particular gravity, can criminal law elevate them to the highest category of unlawfulness, to criminal, which is, in turn, only and exclusively by creating a Tatbestand. ${ }^{11}$

The Tatbestand is, in this sense, the gateway to unlawfulness in the criminal field, but also, and especially, the legislative expression of the material offence that

10 CORREIA, 1999 (reimpressão), p. 281; MEZGER, 1933, p. 176. On the theory of the Unrechtstatbestand in Portuguese doctrine, see HÜNERFELD, 1981, p. 176 ss.

11 See D'AVILA, 2005, passim; and from the same author, Ofensividade em direito penal. 2009, passim. 
precedes and underpins it. It is the result of the difficult task of translating into words the fragment of reality that one wishes to prohibit; hence, its inherent complexity.

Tatbestand and wrongdoing (Unrecht) can not be confused (FARIA COSTA, 2015, p.216). What is here highlighted is not the conceptual autonomy of such categories, but the deep and intertwined interdependence between them. And that is such a way that there can be no criminal offence without Tatbestandsmäßigkeit - all criminal offences require wrongdoing (Unrecht) and Tatbestandsmäßigkeit -, nor can there be Tatbestandsmäßigkeit without wrongdoing (Unrecht) - any Tatbestand is Unrechtstatbestand. Here lies what is most relevant. Neither has material autonomy in isolation. Tatbestand and wrongdoing share the same background and the same meaning, constituting, in substantial terms, a unit, a single systematic category: the Unrechtstatbestand ${ }^{12}$

\subsection{THE ELEMENTS OF DEVALUATION OF THE UNRECHTSTATBESTAND: HANDLUNGSUWERT AND ERFOLGSUNWERT}

The Unrechtstatbestand consists of two indispensable centers of devaluation: Handlungsuwert and Erfolgsunwert. ${ }^{13}$ Besides, together they form a unity of meaning, although it has in its resultant value its fundamental nucleus, ${ }^{14}$ insofar as it

12 Faria Costa rightly states that "the conception of punishable conduct is therefore a two-fold conception, integrating, on the one hand, the Unrechtstatbestand - as a unit of meaning in the first line objectively devalued - and, on the other hand, the guilty" (FARIA COSTA, 2015, p.179). Thus, in essence, Figueiredo Dias: "the conclusion to be drawn from what is said is that, in a functional teleological system of the doctrine of crime, there is no place for a construction that separates, in autonomous categories, the Tatbestand and Unrecht. Systematic category, with autonomy conferred by a teleology and a specific function, is only the category of ilícito-típico or tipo-de-ilícito" (FIGUEIREDO DIAS, 2007, p. 270).

${ }^{13}$ See JESCHECK; WEIGEND, 1996, p. 238 ss.; KÜHL, 2017, p. 17 s.

${ }^{14}$ Although there is some consensus on the relevance of both referentials of Handlungsuwert and Erfolgsunwert in the constitution of the unlawful, the same can not be said about its indispensability ie, the possibility of a criminal offense devoid of Erfolgsunwert or Handlungsunwert - but also not the prevalence of the Erfolgsunwert on the Handlungsunwert. Its trajectory, in fact, is strongly marked by advances and setbacks that are largely explained by the fact that the criminal offense is directly imbricated with the foundation, meaning and function that are assigned to criminal law. Welzel, for example, advocated an understanding in which the undervalue of outcome ceased to have the leading role in the past, giving rise to the devaluation of action in the position of center and foundation of criminal wrongdoing. Although Welzel recognizes the importance of the Erfolgsunwert and believes that their occurrence can be avoided through the punishment of Handlungsuwert, the primary task of 
consubstantiates the teleological reference of the norm, only in the presence and convergence of both (Handlungsuwert and Erfolgsunwert) can achieve criminal dignity and, thus, to found the Unrechtstatbestand bound.

The Handlungsunwert must encompass all the different aspects of the conduct itself, whether subjective or objective, to adequately express it in axiological terms. It comprises, on the one hand, the (i) subjective devaluation of the conduct, that is, the will that presides the conduct of the conduct. Murder is, therefore, more serious than manslaughter, even though the outcome of the action is precisely the same. On the other hand, there is the (ii) objective devaluation of the conduct itself, understanding the manner and form through which the action is practiced. In this scenario, whenever the murder is committed "by treason, by ambush, or by concealment or other recourse that makes it difficult or impossible to defend the victim" (art. 121, IV , CP), it becomes more serious, giving rise to their qualified form. Finally, (iii) the objective elements of authorship play an important role in the formation of the devaluation of action. For example, misappropriation is more reprehensible when the active subject is a civil servant, resulting in a different offence (article 312, CP, embezzlement) of that practiced by those who do not have this qualification (article 168, CP, misappropriation) ${ }^{15}$.

From this conception, the form and intensity with which the conduct reaches the object of protection of the norm, within the scope of the Erfolgsunwert, is placed

criminal law was not, for him, the protection of legal goods, but rather the guarantee of the "real (observance) of the values of the act (Aktwerte) of the juridical conscience"( WELZEL, 1969, p. 1 ss). In his view, "the values of the act such as fidelity, obedience, respect for the person, etc., have a greater breath and a broader vision than the mere protection of goods" (WELZEL, 1969, p. 4). Which leads him to profess a notion of unlawful centered mainly on the Handlungsuwert, a conception in which the result appears as an element even expendable in some cases: "the objective devaluation [the injury or danger to the legal good] may be lacking in the concrete case without the disappearance of the Handlungsuwert, as, for example, occurs in the inidone attempt". (WELZEL, 1969, p. 62).

${ }^{15}$ The systematic arrangement proposed here, however, is not peaceful. There is no doubt that in the Handlungsuwert lies not only the deceit but also the subjective elements of the Tatbestand (subjective devaluation of conduct). But the same can not be said with regard to the location of the elements referring to the form or mode of execution (objective devaluation of the conduct), as well as the objective elements of the authorship. The problem does not arise, Roxin observes, if it applies his conception of the Handlungsuwert as 'unity of objective-subjective sense', since from this perspective even the result is included in the Handlungsuwert. However, Roxin goes on to argue, if a conception of exclusively subjective worngdoing were adopted, these elements would have to be included in the Erfolgsunwert, or else in a 'third' category of depreciation. ROXIN, 2006, p. 327 s. 
outside the Handlungsuwert. The Handlungsunwert here is worthless of the devaluation of offence. It is not to be confused with the result from a natural perspective, understood as a modification of the outer world, nor with the object of the action. It is the devaluation expressed by the offence to legal-criminal good, by the injury or danger of injury the object of protection of the norm. A nucleus of depreciation that, by expressing, through its criminal categories (legal good and offensiveness), the rupture of the original relationship of danger care, assume as the core of the wrongdoing, an expression of the contrariety not only of the legalnormative intentionality but to the very function of criminal law. ${ }^{16}$

Handlungsuwert and Erfolgsunwert, therefore, once correctly conjugated, having the latter as an axiological reference first, give shape to the scope of protection of the Tatbestand and, thus, the steady beacons of the Tatbestandsmäßigkeit judgment. It is now essential to turn a blind to the specific criminal factuality of Article 1 of Law 8.137/90.

\section{THE UNRECHTSTATBESTAND OF TAX EVASION (ARTICLE 1 OF LAW 8.137/90). CONSTITUTIVE ELEMENTS}

\subsection{THE OBJECTIVE STRUCTURE OF ART. 1 OF LAW 8137/90. FRAUD AND THE PROTECTION ACTION IN THE CONSTITUTION OF THE UNRECHTSTATBESTAND}

The legal Tatbestand of art. 1 of Law 8137/90 - the basic norm of both reference cases (see above) - is worded as follows:

Art. $1^{\circ}$ It is a crime against the tax order to suppress or reduce tax, or social

16 As we can see, we start from a conception of the unlawful-typicality based on the ontoanthropological dimension of care of danger, proposed by Faria Costa (FARIA COSTA, 2000, p. 16 ss.). It is, therefore, in this understanding that we conceive the Erfolgsunwert as a category conceived from the violation of that same original relation. It becomes evident that the Erfolgsunwert is not exhausted within the limits of harm/infraction. It must, on the contrary, be understood in the richness of meaning it expresses, that is, in the purest and limpid devalue of care. 
contribution and any accessory, through the following conducts: I - to omit information, or to give false information to the fiscal authorities; II - to fraud tax inspection, inserting inaccurate elements, or omitting operation of any nature, in a document or book required by the tax law; III - forge or alter invoice, duplicate, sales note, or any other document related to the taxable transaction; IV - to elaborate, distribute, supply, issue or use document that knows or should know false or inaccurate; $V$ - deny or fail to provide, where required, invoice or equivalent document, regarding the sale of goods or rendering of service, effectively carried out, or provide it in disagreement with the legislation.

The crime of tax evasion provided for in article 1 of Law 8.137/90 is constituted by two devaluation centers, duly distributed in the nuclei that report the general offence of the Unrechtstatbestand (Handlungsunwert and Erfolgsunwert), which, once combined, give it dignity and material legitimacy. These are (i) the use of fraud, to operate in Handlungsunwert, and (ii) treasury losses, in Erfolgsunwert.

The notions of fraud and treasury losses, therefore, not only guide the constitution of the crime in its objective dimension but are, in truth, founding elements of the material unlawful of a criminal nature. In other words, in the light of the Unrechtstatbestand of art. 1 of Law 8.137/90, in the absence of fraud or treasury losses, there is no crime. ${ }^{17}$ This, moreover, is not surprising. As is well known, the indispensable combination of these elements for the formation of the objective Tatbestand enjoys a broad consensus in specialized criminal (and tributary) literature.

Leandro Paulsen understands that:

The difference between simple default and tax evasion is the use of fraud (PAULSEN, 2017, p.359). (...) "The art. 10 defines material crimes that, therefore, have as an objective condition of punishability the definitive release of the respective taxes (S.V. №. 24)." (PAULSEN, 2017, p.360 ss) (...) The typical conduct is to suppress or reduce tribute (social contribution is also tribute) and any accessory through the fraudulent means that art. $1^{\circ}$ predict (PAULSEN, 2017, p.361).

In the same sense, José Paulo Baltazar Júnior argues:

The crime against the tax order presupposes, in addition to the default,

17 In this sense, Baltazar Júnior: "that is, without fraud and suppression or omission of taxes there is no evasion" (BALTAZAR JÚNIOR, 2017, p. 815). 
some form of fraud, which may be embodied in the omission of some declaration, in the material or ideological falsification of documents, in the use of material or ideologically false documents, in simulation, etc. Fraudulent conduct is described in subsections of arts. $1^{\circ}$ and $2^{\circ}$ of Law 8.137. Here is the distinction between default and evasion: fraud. (...) (BALTAZAR JÚNIOR, 2017, p.797) The crime of tax evasion, in general, consists of the sum of the suppression or reduction of taxes with the acting of fraud in at least one of the law's subsections (BALTAZAR JÚNIOR, 2017, p.805).

And, finally, in the words of Cezar Roberto Bitencourt (2016, p.723 s):

\begin{abstract}
The specificity of the object of criminal protection in this art. 10, justifies the content of the behaviors incriminated in subsections I to $\mathrm{V}$, since they represent, from the point of view of the Tax Law, the non-compliance with tax requirements aimed at certifying the birth of the tax obligation and to facilitate the control and collection of the amount due with the tribute. In fact, the listed conduits have significant offensive potential, insofar as they obstruct and/or avoid tax collection activity, negatively affecting the functions performed by taxes. But, as we shall see throughout this Chapter, they will only be criminally relevant for subsumption effect in the Tatbestand of art. $1^{\circ}$ when they involve the reduction or fraudulent suppression of tax or accessory, or, at least, in its attempt.
\end{abstract}

The same understanding can be found in national jurisprudence, as is well illustrated in Habeas Corpus no. 135.426 / SP, judged on February 26, 2013, by the $5^{\text {th }}$ Group of the Superior Court of Justice [STJ], with a report by Min. Jorge Mussi; the Criminal Appeal n. 5008891-33.2011.404.7002 / PR, judged on May 8, 2014, by the $8^{\text {th }}$ Group of the Federal Regional Court of the 4th Region [TRF4], with a report by Appeal Judge João Pedro Gebran Neto; the Criminal Appeal n. 500172720.2012.4.04.7119 / RS, judged on July 7, 2017, by the $8^{\text {th }}$ Group of the Federal Regional Court of the 4th Region [TRF4], with a report by Appeal Judge Leandro Paulsen; the Criminal Appeal n. 0077012-72.2002.8.26.0050, judged on 12.12.2017, by the $3^{\text {rd }}$ Chamber of Criminal Law of the Court of Justice of São Paulo [TJSP], a report by Appeal Judge Airton Vieira, among other judgments.

This precise legal framework, however, could not be different. In fact, what we have here is nothing more than the logical and direct consequence of the tutelage proposed by Law $8.137 / 90$ in its article 1, that is, a guardianship that seeks its material autonomy in relation to the respective administrative infraction, from an 
object of pluri-axiological protection, in casu, of a protected object endowed with two dimensions.

While there may be some doctrinal oscillation about the amounts under protection in the crime of tax evasion (Articles 1 and 2 of Law 8.137/90), it is undeniable that, under Brazilian Law, criminal unlawfulness starts from a pecuniary horizon, in line with some criminal proceedings, such as German ( $\$ 370$ AO Steuerhinterziehung), ${ }^{18}$ but did not suit with it. There is more than one dimension of protection to regulate the legal good, so as to endow it with legal-criminal dignity.

It is not here under discussion that the tax collection constitutes an interest in extreme protection by the Unrechtstatbestand of tax evasion or, at least, real expression (concretization) of the patrimonial dimension of the protected legal good. ${ }^{19}$ This good, by its nature, reveals in the non-perception of the respective values by the treasury a clear form of offence in the modality of injury. ${ }^{20}$

This fact, then, is unquestionable to our understanding. However, it is equally valid that the mere patrimonial protection of the treasury is not sufficient for the constitution of criminal wrongdoing. Simple default is a matter to be regulated by noncriminal orders, such as administrative and civil, but not, given their formal and material particularities, by the criminal legal system. The entry into the qualified space of criminal unlawfulness presupposes the affectation of the second dimension of protection, usually denominated truth-transparency, as a result of the "security and

18 See DÖRN, 2001, p.15; KOHLMANN, 1997; JOECKS, 1996, p.140.
19 Heloisa Salomão, as well as a significant part of the specialized literature, proposes "tax collection"
as an effective protected legal good. According to the author, tax collection is capable not only of
"capturing the static and dynamic potentialities of the constitutionally attributed value" to the tax
system, but also of "exercising the functions of limiting ius puniendi and of a critical instrument of
positive law". (SALOMÂO, 2001, p.188, 207 e 221). Athough we can follow the reasons and concerns
expressed by the author, however, we are not so sure about the sufficient axiological resonance of the
tax collection, as a value in itself, to the point of giving it the autonomy minimally necessary to appear
as a true criminal legal good. That's the reason we choose the reference of implementation in strict
terms. Also with regard to Brazilian doctrine, we can mention, by way of illustration, the lesson of Rui
Stoco, according to which, the legal object, in crimes against the tax order, consists of "state interests
linked to the collection of taxes owed to the Treasury", through which the public faith and the Public
Administration are mainly served. The author emphasizes that the "immediate object is the
suppression or reduction of tribute, and the mediate is variable in each of the figures" (STOCO, 2001,
p.612).
20 Vide NANNUCCI, 2000, p.253 s.; ZANNOTI, 2002, p. 152 s.; TRAVERSI; GENNAI, 2000, p.54;
CADOPPI, 1988, p. 640 s.; BARTULLI, 1962, p.255; DELOGU, 1965, p.421 ss.; STOCO, 2001, p.612
S.; SALOMAिO, 2001, p.221. 
reliability of legal traffic with documents in the specific field of fiscal practice" (FIGUEIREDO DIAS, 1996, p.63 s e 66).

Regarding the Brazilian legislation, the legal good under protection in the crime of tax evasion is formed by the meeting of two distinct values, one of a patrimonial nature, expressed and concretized in the tax collection, and another, of a non-patrimonial nature, consistent in the notion of truth-transparency. Both of them demand, pursuant to article 1 of Law 8.137/90, an effective injury offence. The first, as a result of the expression suppression or reduction of tax, and the second, due to the requirement of fraudulent means.

The articulation of both dimensions of the juridical object, as is usual in crimes endowed with pluri-axiological legal good (i.e., legal goods conforming to more than one value), may give rise to different protectives techniques, sometimes in the form of formal crimes, others, of material crimes. This is the case of Article 2, inc. I of Law 8.137/90, which, according to the Portuguese legal system, gives rise to a formal offence (based on the naturalistic result), centred on the truth-transparency dimension.

Article 1, however, is manifestly a material crime (as to the naturalistic result) and injury (as regards the legal good). Consequently, both fraud and treasury losses are absolutely indispensable for the consummation of the crime. The fraud, however, with an critical differential, assumes a central role in the conjugation of values under protection. It is precisely the fraud - as we have already observed - the factor responsible for the inflow of the treasury losses in the sphere of legal-penal interest. It is the fraudulent means that makes the criminal offence an aliud in relation to simple administrative default, to allow, consequently, its desired autonomy with regard to the administrative-tax order. In a direct way: without fraud, there is no tax evasion.

In the specific case of article 1 of Law $8.137 / 90$, by means of the protective technique employed, it was chosen to enumerate the hypotheses of fraud throughout the five subsections that structure the Tatbestand. This means that all the hypotheses discriminated against try to express a modality of fraud and must be interpreted from this idea. The legal Tatbestand (gesetzlicher Tatbestand) is a positive formulation, 
teleologically oriented to the protection of the legal interests that constitute and animate it, only in this way, through a teleologically compromised hermeneutics, it is possible to delimit the Tatbestand scope of incidence and, consequently, to safeguard the rationality of the criminal unlawfulness and Tatbestandsmäßigkeit. Therefore, in the absence of trickery, fake, malice, one should not speak of fraud, and thus also not in the realization of the criminal Tatbestand. The mere misunderstanding of bookkeeping, or even a small divergence from the understanding adopted by the tax authorities, does not constitute a fraudulent use to avoid the objective realization of the Unrechtstatbestand.

It is correct to say, in the objective dimension of the criminal Tatbestand, of tax evasion foreseen by art. 1 , subsections I to $V$ of Law $8.137 / 90$, that the treasury losses (in terms of Erfolgsunwert) and fraud (Handlungsunwert) are constitutive elements of the crime (genuine founding aspects of the material illegality itself of criminal nature), and in the absence of fraud or treasury losses there is no crime for lack of objective Tatbestandsmäßigkeit.

\subsection{THE STRUCTURE OF THE SUBJECTIVE ELEMENT OF ART. 1o OF LAW $8137 / 90$}

The notion of fraud or fraudulent means constitutes a founding element of the criminal unlawfulness and Tatbestand of Article 1 of Law 8.137/90 - corresponds, in dogmatic terms, to an elementary ruler of a normative nature that will find concreteness in the behaviours listed in the subsections of art. 1. As well seen, by insurmountable dogmatic demand, each of them must be understood in the strict limits of its elementary trend, the fraud. So far, however, there is nothing new. As already amply explained, the requirement of fraud for the constitution of the criminal Unrechtstatbestand finds a significant consensus in jurisprudence and specialized doctrine. The peculiarity lies in the fact that the very notion of fraud, while normative, holds an internal teleology of its own, which invokes the subjective dimension of the Unrechtstatbestand.

It is well known that, alongside elementary descriptions, the legal Tatbestand 
(gesetzlicher Tatbestand) may present elementary normative and subjective nature, both results of essential developments of the Neo-Kantian thought. ${ }^{21}$ The first ones the elementary normative - are characterized by not being accessible from simple sensory activity. Their knowledge is only reached by means of a value of judgment, whose reference can be found in norms in general, criminal or not, or even in other non-juridical axiological dimensions, such as culture. This is the case of elementary "others," in the crime of theft (art.155 CP), "falsely" in the crime of slander (art 138 $\mathrm{CP}$ ) or "unlawful" in stellionato (art $171 \mathrm{CP}$ ). The second ones - the subjective elementals - are related to certain intentions that not only mark the direction of conduct but are indispensable for the correct understanding and delimitation of the matter of prohibition. The most common example is the elemental "for himself or for others" in the legal Tatbestand of theft (article $155 \mathrm{CP}$ ), without which the criminal Tatbestand has not materialized itself.

Fraud is a clear example of elementary normative, given the need for a judgment of value to be known. However, unlike other elementary norms which are entirely restricted to the objective dimension of the Unrechtstatbestand, fraud is only constituted as such if it is associated with a specific intention: the intention to deceive, mislead. In the absence, a supposed false may prove to be a misconception of filling, the omission, a mere forgetting. This is because fraud is nothing more than a tricky means, a means of deceit (rectius: a mean/trick that seeks to deceive) and, as a means/path to something, necessarily presupposes a direction in a specific direction: deceit, the induction in error.

It is, therefore, an element of a hybrid nature, in which the value of judgment of elementary normative must also be projected on the psychological direction of

21 The discovery of normative elements of the legal Tatbestand is usually attributed to Max Ernst Mayer. In his studies, Mayer verified in the legal Tatbestand the existence of elements lacking in valuation - proper of unlawfulness; a kind of "foreign body" among the descriptive elements of the Tatbestand, thus calling them "improper elements of Tatbestandsmäßigkeit " (MAYER, 1923, p. 184.). It observes that the proper elements of unlawfulness, different from the elements of Tatbestandsmäßigkeit, would be not only indications of unlawfulness (ratio cognoscendi), but its own foundation (ratio essendi), and that this precise characteristic would be present in normative elements of legal Tatbestand. (MAYER, 1923, p. 184 s.). In addition, in the same sense, it was initially observed by Fischer (see MEZGER, 1933, p. 168), authors such as Mayer and Mezger begin to recognize in the Tatbestand also elements of a psychological nature, originating from an internal dimension of the author (MAYER, 1923, p. 7 s. e 185 ss.; MEZGER, 1933, p. 168 ss. e 190). 
action, advancing on aspects proper to the subjective elementary, in order to obtain, in this way, the social and legal-criminal sense of the fact.

In practical terms, such characteristics of the Tatbestand lead to an overestimation of the subjective dimension of the criminal Unrechtstatbestand. Although Article $1^{\circ}$ of Law No. 8,137/90 is a willful crime, the absence of representation of fraudulent conduct and the will to carry it out, rather than dismissing the subjective imputation for lack of intent, removes the objective imputation itself for not characterizing fraud.

\section{CONCLUSION}

In the first case, as already examined, the indicted was charged with the conduct described in art. 1, II, of Law 8137/90. The legal Tatbestand of the conduct described in art. 1, caput, of Law 8137/90, it is to suppress or reduce taxation, and in the following five subsections are highlighted the various modalities - fraudulent, reiterate. Under the terms of the complaint, the accused would have reduced taxes by inserting undue ICMS credits into a mandatory fiscal book through the practice described in inc. II of art. 10, that is, through the insertion of inaccurate elements in a book required by the tax law.

It should be emphasized that such a crime is a material crime (as to the naturalistic result) and an injury crime (as regards the legal good). Consequently, both fraud and treasury losses are essential elements in its configuration. The fraud, also as already registered, with a central role in the constitution of the wrongdoing, since it is through it - and only through it - that the fact reaches effective criminal dignity.

However, this is not the case. The indicted did not include in the fiscal book information that does not correspond to reality. On the contrary, entered precisely the amount of ICMS credit highlighted in the Invoice. The resignation is limited to the fact that the State of Santa Catarina considers, on the basis of infra-legal regulations, that the amount, although strictly correspondence with the factual reality, is unduly 
included. In other words, it argues that the non-recognition of the right to ICMS tax credit by the treasury is ipso facto equivalent to fraud; Or even if the taxpayer's interpretation of the legislation differently from what the tax authority does, it is necessarily synonymous with trickery, false, malice.

In an effort to simplify the situation, the prosecutor's plea can be summed up as follows: a) if the taxpayer's claim was not recognized by the tax authorities, it is undue; b) if it is improper, it is consequently inaccurate/false; c) therefore if it is inexact or wrong, it is necessarily fraudulent.

Now such an understanding of things - regrettably recurrent in the criminal tax field - consists of the clearest in terms of logical and methodological subversion of the dogmatic parameters which inform (rectius, they must inform) the constitution of the criminal Unrechtstatbestand. This is not what the crime of tax evasion is all about.

Even if the existence of tax Tatbestandsmäßigkeit can be defended, the absence of fraud rejects the objective dimension of the Unrechtstatbestand, and thus, by everything already above advanced, also its indispensable subjective dimension (absence of a will).

Regarding the second, it is necessary to take into account that the tax crime under analysis is a pluriaxiological normative formulation, conformed, therefore, by more than one legal good. As alreadu examined the tax crimes protect the tax collection (in a clear patrimonial bias) - which is evidenced in the legal expression of "suppression or reduction of tribute" in the caput of art. 1 of Law no. 8137/90. But at the same time, protect the notion of truth-transparency, stamped in the legal requirement of the fraudulent conduct described in the paragraphs of the art. 1. There is only a tax crime when there is an effective offence (injury or danger) to the goods tax collection and truth-transparency.

If there is an offence only to tax collection, without any violation of truthtransparency, the action may be administratively repressed. Criminally, however, certainly not. If there is an exclusive offence to the truth-transparency, but this does not represent a patrimonial loss (effective or potential) to the tax authorities, once again comes the scene the possibility of an unlawful-tributary remains configured, but never a tax evasion crime. 
Considering the case analysis, the managing partner of the transport company was charged for having credited the ICMS amounts included in the invoices of the materials purchased for the maintenance of the fleet of vehicles, without, however, having prepared the reports that were required by the current RICMS. ${ }^{22}$ It is, therefore, a mere non-fulfillment of an ancillary obligation (which is related to the exercise of State supervision), devoid of any repercussion. There was, in casu, no suppression or reduction of tribute. There was no (patrimonial) loss to the tax authorities. The managing partner was careful to credit strictly the credits posted in the invoice. Not a penny more, not a penny less. Only the constitutional guarantee resulting from the principle of non-cumulative with regard to ICMS was used.

Once again faced with a factual substrate capable of consubstantiating an administrative but not a criminal offence. Given the absence of an offence against the object of protection of the norm (simultaneous offence to the legal goods assets and truth-transparency), there is no way to speak of a tax evasion crime.

Everything, demonstrates the need for greater attention to the particularities that constitute and grant autonomy to the orders of tax and criminal regulation. Although the importance of a constant dialogue between tax law and criminal law can not be denied - and this is a piece of evidence - it must be borne in mind that the usefulness of this dialogue is the mutual recognition of identities that give meaning to their coexistence.

\section{REFERENCES}

ÁLVAREZ ECHAGUE, Juan Manuel. La extinción de la acción penal tributaria. Buenos Aires: Ad-Hoc, 2018.

BALTAZAR JÚNIOR, José Paulo. Crimes federais, 11 edª̣, São Paulo: Saraiva, 2017.

${ }^{22}$ In this article - for a matter of time and methodological reasons - we will not enter into the discussion about the (possibility of) retroactivity of the complement of the blank criminal law, when there is beneficial and subsequent change of the norms established in the RICMS. However, if there is interest on the part of the reader in the deepening of this point, we note that the subject has already been dealt with in the Norma penal em branco e outras técnicas de reenvio em Direito penal, co-authored by Fábio André Guaragni and Marion Bach, published by Editora Almedina, in the year 2014. 
BARTULLI, Armando. Condotta omissiva e accertamento del dolo nel reato di frode fiscale. Sc. pos., 1 (1962).

BECKER, Alfredo Augusto. Teoria Geral do Direito Tributário. $4^{\text {a }}$ ed. São Paulo: Noeses, 2007.

BELING, Ernst. Die Lehre vom Verbrechen, Tübingen: J.C.B. Mohr, 1906.

BITENCOURT, Cezar Roberto. Tratado de direito penal econômico, vol. 1, São Paulo: Saraiva, 2016.

CADOPPI, Alberto. II reato omissivo proprio. Profili introduttivi e politico-criminale, vol.1. Padova: CEDAM, 1988.

CARVALHO, Paulo de Barros. Curso de direito tributário. 25 ed. São Paulo: Saraiva, 2013.

CATANIA, Alejandro J. Régimen penal tributario. Estudio sobre la ley 24.769. Buenos Aires: Editores del Puerto, 2005.

CORREIA, Eduardo. Direito Criminal, com a colaboração de Jorge de Figueiredo Dias, Coimbra: Coimbra Editora,1999.

D'AVILA, Fabio Roberto. Ofensividade em direito penal: escritos sobre a teoria do crime como ofensa a bens jurídicos. Porto Alegre: Livraria do Advogado Editora, 2009.

Ofensividade e crimes omissivos próprios. Contributo à compreensão do crime como ofensa ao bem jurídico, Coimbra: Coimbra Editora, 2005.

DELOGU, Tullio. L'oggetto giuridico dei reati fiscal. In: Studi in onore di Francesco Antolisei, vol. I, Milano: 1965.

DÖRN, Harald. Steuerhinterziehung durch Unterlassen?, Baden-Baden: Nomos, 2001.

ENGISCH, Karl. Die normativen Tatbestandselemente im Strafrecht. In: Festschrift für Edmund Mezger zum 70o Geburtstag, München; Berlin: 1954.

FARIA COSTA, José de. Ilícito típico, resultado e hermenêutica. Ou o retorno à limpidez do essencial. Seminário internacional de direito penal, Universidade Lusíada, Lisboa: Universidade Lusíada, Mar. 2000.

Noções fundamentais de direito penal. Fragmenta iuris poenalis, 4. ed., Coimbra: Coimbra Editora, 2015. 
FERRAZ JUNIOR, Tércio Sampaio. Obrigação tributária acessória e limites de imposição: razoabilidade e neutralidade concorrencial do Estado. In Teoria Geral da Obrigação Tributária: estudos em homenagem ao Professor José Souto Maior Borges. Heleno Taveira Torres (org.). São Paulo: Malheiros, 2005.

FIGUEIREDO DIAS, Jorge de. Direito Penal. Parte geral, 1. ed. brasileira, 2. ed. portuguesa, Coimbra: Coimbra Editora, 2007.

FIGUEIREDO DIAS, Jorge de; COSTA ANDRADE, Manuel da. O crime de fraude fiscal no novo direito penal tributário português. Considerações sobre a factualidade típica e o concurso de infracções. RBCCr, 13, 1996.

FUCHS, Helmut. Strafrecht. Allgemeiner Teil I. Grundlagen und Lehre von der Straftat, 8ª ed., Wien: Springer, 2012.

GUARAGNI, Fábio André; BACH, Marion. Norma penal em branco e outras técnicas de reenvio em Direito penal. São Paulo: Almedina, 2014.

HÜNERFELD, Peter. Strafrechtsdogmatik in Deutschland und Portugal. Ein rechtsvergleichender Beitrag zur Verbrechenslehre und ihrer Entwicklung in einem europäischen Zusammenhang, Baden-Baden, Nomos, 1981.

JESCHECK, Hans Heinrich; WEIGEND, Thomas. Lehrbuch des Strafrechts. AT, 1996.

JOECKS, Wolfgang, in: FRANZEN/GAST/JOECKS, Steuerstrafrecht mit Steuerordnungswidrigkeit und Verfahrensrecht. Kommentar. §§ 369-412 AO, § 32 ZollVG, 4. ed., München: Beck'sche, 1996.

KINDHÄUSER, Urs. Strafrecht. Allgemeiner Teil, 3. ed., Baden-Baden: Nomos, 2008.

KÜHL, Kristian. Strafrecht. Allgemeiner Teil, 8. ed., München: Franz Vahlen, 2017.

MAYER, Max Ernst. Der allgemeine Teil des deutschen Strafrechts. Lehrbuch, $2 .$. ed., Heidelberg: Carl Winters Universitätsbuchhandlung, 1923.

MEZGER, Edmund. Strafrecht. Ein Lehrbuch, 2. ed., München; Leipzig: Duncker \& Humblot, 1933.

NANNUCCI, Ubaldo. II delitto di omessa dichiarazione. In: La riforma del diritto penale tributario (D.Igs.10 marzo 2000 n.74), org. por Ubaldo Nannucci e Antonio D’Avirro, Padova: Cedam, 2000.

PAULSEN, Leandro. Crimes federais, São Paulo: Saraiva, 2017. 
RENGIER, Rudolf. Strafrecht. Allgemeiner Teil, 5., München: Verlag C. H. Beck, 2013.

ROXIN, Claus. Strafrecht. Allgemeiner Teil, vol. 1, 4. ed., München: C. H. Beck, 2006.

SALOMÃO, Heloisa Estellita. A tutela penal e as obrigações tributárias na Constituição Federal, São Paulo: Revista dos Tribunais, 2001.

STEININGER, Einhard. Strafrecht. Allgemeiner Teil. Eine Einführung, 2. ed., Wien: Linde, 2013.

STOCO, Rui, in: FRANCO/STOCO, Código Penal e sua interpretação jurisprudencial, vol.1, parte geral, 7. ed. São Paulo: Revista dos Tribunais, 2001.

STRATENWERTH, Günter; KUHLEN, Lothar. Strafrecht. Allgemeiner Teil I, 5. ed., Köln; Berlin; München: Carl Heymanns Verlag, 2004.

TRAVERSI, Alessandro; GENNAI, Sara, I nuovi delitti tributari, Milano: Giuffrè, 2000.

VIEIRA, José Roberto. A regra-matriz de incidência do IPI: texto e contexto. Curitiba: Juruá, 1993.

ZANNOTI, Roberto. I/ delitto di omessa dichiarazione. In: Diritto penale tributario, org. por Enzo Musco, Milano: Giuffrè, 2002.

WELZEL, Hans. Das deutsche Strafrecht. Eine systematische Darstellung, 11. ed., Berlin: Walter de Gruyter, 1969.

WESSELS, Johannes; BEULKE, Werner. Strafrecht. Allgemeiner Teil, 30. ed., C. F. Müller, 2000. 